DOI: $10.19195 / 2300-7729.37 .11$

\author{
KATARZYNA KRZAK-WEISS
}

ORCID: 0000-0003-0741-3281

Uniwersytet im. A. Mickiewicza w Poznaniu

\title{
Jak Emil Zegadłowicz o typografii gawędził. Uwagi na marginesie poznańskiej edycji Gawędy poety z typografem z 1929 roku
}

W poniedziałek d. 28. maja otworzył obrady Emil Zegadłowicz piękną prelekcją pod tytułem „Gawęda Poety z Typografem”, domagając się w szeregu głębokich myśli harmonijnego zcalenia i syntezy treści z kunsztem typograficznym i wyczarowania swoistego typu prawdziwie pięknej książki polskiej ${ }^{1}$.

Tak wystąpienie Emila Zegadłowicza skomentowane zostało w Pamiętniku Trzeciego Zjazdu Bibljofilów Polskich, w którym skrzętnie odnotowano wszystkie wydarzenia, mające miejsce we Lwowie w dniach 26-29 maja 1928 roku i upamiętniające stulecie Ossolineum. W tymże pamiętniku znalazł się również tekst prelekcji gorzeńskiego poety, w ten sposób po raz pierwszy zyskując utrwaloną drukiem postać ${ }^{2}$ I choć publikację upamiętniającą lwowski zjazd wydano całkiem starannie, a część jej nakładu wręcz w iście bibliofilskim stylu, bo na oryginalnym japońskim papierze czerpanym ${ }^{3}$, to jednak o wiele atrakcyjniejszą i adekwatniejszą do treści formę tekst Zegadłowicza otrzymał nieco później, staraniem zaprzyjaźnionego z poetą Jana Kuglina ${ }^{4}$. To właśnie dzięki niemu w 1929 roku, w mieszczącej się w Poznaniu i kierowanej przezeń Rolniczej Drukarni i Księ-

1 Pamiętnik Trzeciego Zjazdu Bibljofilów Polskich we Lwowie w Zielone Świątki 26/V-29/V 1928 roku, red. K. Hartleb, Lwów 1929, s. 22 (pisownia oryginalna).

2 Ibidem, s. 33-43.

3 Według notki zamieszczonej na karcie poprzedzającej właściwy tekst Pamiętnika tom ten został wydany w nakładzie sześciuset siedemdziesięciu numerowanych egzemplarzy, z których siedemdziesiąt wytłoczono na oryginalnym japońskim papierze czerpanym, a resztę na matowym papierze bezdrzewnym (Pamiętnik..., s. [5]).

${ }^{4}$ E. Zegadłowicz, Gawęda poety z typografem, Poznań 1929. Wydanie to zostało zresztą dedykowane poznańskiemu drukarzowi, o czym świadczy umieszczony na karcie dedykacyjnej zapis: „Janowi z Bogumina Kuglinowi Autor”. 
garni Nakładowej, powstała edycja mogąca śmiało aspirować do miana pięknej i stanowiąca namacalny dowód możliwości realizacji postulowanego przez Zegadłowicza „harmonijnego zcalenia i syntezy treści z kunsztem typograficznym”.

\section{[...] najszlachetniejsza miłość do ksiąg ${ }^{6}$}

Powierzenie wydania Gawędy poety z typografem oficynie kierowanej przez Kuglina nie było przypadkowe. Autor utworu i drukarz — rzec by można tytułowi bohaterowie tekstu — znali się bowiem już od dwóch lat i darzyli nawzajem szacunkiem oraz przyjaźnią, którym początek dała inna wspólnie stworzona książka - W obliczu gór i kulis. Druk ten, będący zbiorem referatów i poematów powstałym z inicjatywy Jana Jachowskiego, który w ten sposób zapragnął uświetnić początek pracy Zegadłowicza na stanowisku kierownika literackiego Teatru Polskiego w Poznaniu, wyraźnie przypadł poecie do gustu, bo wkrótce po tej „pierwszej wspólnie zrodzonej”7 książce przyszły kolejne ${ }^{8}$. Obu twórców, których los zetknął w stolicy Wielkopolski, połączyło wiele, zwłaszcza umiłowanie gór, z których obaj pochodzili, a ponadto „najszlachetniejsza miłość do ksiąg”, przejawiająca się $\mathrm{w}$ zaangażowaniu w ruch bibliofilski ${ }^{10}$ oraz upodobaniu do druków wydanych pięknie i starannie.

Owo uwielbienie dla książki pięknej nie było zresztą w tamtym czasie wyjątkowe, bo wpisywało się idealnie w panujące już od kilkudziesięciu lat trendy, które swój początek wzięły od zainicjowanego u schyłku XIX stulecia na Wyspach Brytyjskich przez Emery'ego Walkera oraz Williama Morrisa nurtu

${ }^{5}$ Pamiętnik..., s. 22.

6 Tytuły podrozdziałów są wyimkami z Gawędy.

7 J. Kuglin, Ze wspomnień typografa, Wrocław 1958, s. 23. Słowa te są fragmentem dedykacji zamieszczonej przez Zegadłowicza w egzemplarzu $W$ obliczu gór i kulis podarowanym Kuglinowi.

${ }^{8}$ Przed Gawęda Kuglin wydrukował: Siedem pieśni zgrzebnych o Janie Kasprowiczu (1928), Widma wskazówek (1928), Głośniki płonace (1929) oraz Dziesięć ballad o powsinogach beskidzkich (1929) Zegadłowicza.

9 E. Zegadłowicz, op. cit., s. [3].

10 Więcej na temat rozwijającego się w Polsce w latach dwudziestych XX stulecia ruchu bibliofilskiego oraz obecności w nim Kuglina i Zegadłowicza zob. m.in. J. Sowiński, Działalność edytorska towarzystw bibliofilskich w Polsce do roku 1939, „Roczniki Biblioteczne” 38, 1994, s. 182 n.; J. Mulczyński, Wystawy grafiki i ruch bibliofilski w Poznaniu w okresie dwudziestolecia międzywojennego, „Kronika Miasta Poznania” 1996, nr 4. Lata dwudzieste. Lata trzydzieste, s. 132-154; K. Krzak-Weiss, Poznańskie druki bibliofilskie lat 20. minionego stulecia - coś nie tylko dla ducha, ale również dla oka, [w:] Poznań pisarek i pisarzy, red. J. Borowczyk, L. Marzec, Z. Kopeć, Poznań 2016, s. 185-199. 
beautiful book ${ }^{11}$, szybko przenikającego do innych ośrodków, w tym również na ziemie polskie ${ }^{12}$.

Znakomitym dowodem wczesnej recepcji nowych tendencji w Polsce była twórczość typograficzna Stanisława Wyspiańskiego ${ }^{13}$ oraz (pozostającego nieco w jego cieniu) Józefa Mehoffera ${ }^{14}$. Do ich działań nawiązali zresztą później Zegadłowicz z Kuglinem. Jak wspomina typograf:

Zegadłowicz umiał ocenić formę graficzną książki. [...] Pierwsze przez Zegadłowicza wydane książki, graficznie przez niego samego opracowane, starały się nawiązać do poczynań Stanisława Wyspiańskiego, który pod wpływem Williama Morrisa i angielskich prerafaelitów chciał stworzyć oryginalną książkę polską ${ }^{15}$.

O sobie pisał zaś:

Na piękno w formie zewnętrznej książki i na znaczenie tej formy w rozwoju naszej kultury artystycznej zwrócił mi uwagę Józef Mehoffer, profesor i rektor krakowskiej Akademii Sztuk Pięknych, nieprzeciętnej miary artysta-malarz, witrażysta, a przede wszystkim grafik, który kontynuując poczynania Wyspiańskiego nad podniesieniem piękna w książce, wpłynął poważnie na jej formę estetyczną, szczególnie na jej zdobnictwo w początkach naszego wieku ${ }^{16}$.

Jednak w wypadku Kuglina wzorów do naśladowania i czerpania inspiracji było o wiele więcej, zwłaszcza że jego zainteresowanie zagadnieniem pięknej książki szybko przerodziło się w fascynację, której przejawem było dogłębne studiowanie wszystkiego, co na ten temat się ukazało zarówno w Polsce, jak i poza

11 Więcej na ten temat zob. m.in. J. Wiercińska, W poszukiwaniu absolutnej harmonii, [w:] eadem, Sztuka i ksiązka, Warszawa 1986, s. 47-75 (tam również bibliografia odnosząca się do tego zagadnienia); eadem, Z problematyki zdobnictwa książkowego lat dziewięćdziesiątych XIX w., [w:] Sztuka około 1900. Materiaty z sesji Stowarzyszenia Historyków Sztuki, Warszawa 1969, s. 224 n. Spośród wielu opracowań zagranicznych na szczególną uwagę zasługują zaś: J.R. Dunlap, The Road to Kelmscott. William Morris and the Book Arts before Founding of the Kelmscott Press, London 1972; W.S. Peterson, The Kelmscott Press: A History of William Morris's Typographical Adventure, Berkeley-Los Angeles 1991; J. Christian, A Claim to Beauty. William Morris and the Kelmscott Press, London 2013.

12 Zob. m.in. J. Sowiński, Sztuka typograficzna Młodej Polski, Wrocław 1982; A. Boguszewska, ,Idea pięknej książki” w dwudziestoleciu międzywojennym w Polsce, „Annales Universitatis Mariae Curie-Skłodowska Lublin Polonia" 8, 2010, s. 51-63; G. Bąbiak, Piękna książka na ziemiach polskich u schyłku XIX wieku, ,Sztuka Edycji” 2013, nr 2, s. 19-30.

13 Zob.: P. Smolik, Zdobnictwo książki w twórczości Wyspiańskiego, Łódź 1928; E. Skierkowska, Wyspiański - artysta książki, Wrocław 1960.

${ }^{14}$ H. de Franqueville d'Abancourt, Grafika książowa Józefa Mehoffera na tle prądów współczesnych, Kraków 1929; M. Żmuda, Józef Mehoffer jako wspóltwórca pięknej książki polskiej (praca magisterska obroniona w 1984 roku w Instytucie Informacji Naukowej i Bibliotekoznawstwa UJ pod kierunkiem prof. dr hab. Marii Kocójowej).

15 J. Kuglin, op. cit., s. 22.

16 Ibidem, s. 9. 
jej granicami ${ }^{17}$, a także samodzielna analiza dokonań innych typografów ${ }^{18}$. Rezultatem tych rozpoznań i poszukiwań, dodatkowo skonfrontowanych z realnymi możliwościami, jakimi dysponowała drukarnia, w której pracował Kuglin, stał się opracowany przez niego swoisty model książki idealnej. Jak pisał:

w moich warunkach [...] najwłaściwiej będzie tworzyć książkę nadając jej czystą formę typograficzną, bez elementów zdobniczych. Podstawą natomiast jej estetyki powinna być czcionka o kroju klasycznym, czytelna, tytuły i inicjały czcionkowe, papier najwyższego gatunku, o ile możności szmaciany i ręcznie czerpany, farba zgotowana z sadzy i pokostu, wreszcie format, w którym stosunek szerokości do wysokości tak kolumny, jak i stronic papieru odpowiadać będzie zasadom „złotego podziału”, tj. stosunkowi $3: 5: 8$. Ten sam stosunek obowiązywać powinien w wymiarach marginesów, wielkości opuszczeń w kolumnach początkowych, w odstępach między tytułami a tekstem, w wielkości inicjałów, rozmieszczeniu rycin itd. ${ }^{19}$

I choć ów model, nawiązujący do najlepszych typograficznych tradycji, nie zawsze udawało się Kuglinowi wcielić w życie, to w wypadku przynajmniej kilkudziesięciu pozycji zadanie to powiodło się znakomicie. Stało się tak choćby w drukach wydanych w ramach zainicjowanej przez niego w 1929 roku serii „Biblioteka Studwudziestu" (nazwanej tak od liczby egzemplarzy w jakiej tłoczono poszczególne tytuły ${ }^{20}$, wśród których znalazła się między innymi wytłoczona jako tom drugi (Liber secundus) Zegadłowiczowska Gawęda poety z typografem.

\section{[...] instrumentem głównym drukarza jest czcionka}

Wczytując się w tekst Gawędy, nietrudno zrozumieć organizatorów lwowskiego zjazdu, że do wygłoszenia referatu zaprosili właśnie Zegadłowicza. Swoją znajomością rzeczy, znajdującą wyraz w trafności spostrzeżeń dotyczących pracy

${ }^{17}$ Za jedne z ważniejszych dla siebie tekstów Kuglin uważał Note by William Morris on His Aims in Founding The Kelmscott Press oraz The Ideal Book Thomasa Jamesa Cobden-Sandersona, a także Książkę wytworna Stanisława Lama i pracę Piękna książka jako zespół całości papieru, czcionek, druku i oprawy Bonawentury Lenarta (ibidem, s. 13).

18 Rezultatem studiów Kuglina nad dokonaniami innych typografów był między innymi tekst poświęcony Szwajpoltowi Fiolowi (Świętopetk Fieol z Krakowa i jego druki w Rosji, „Muzeum Polskie" 1918) oraz cykl artykułów o drukarstwie polskim na Rusi wydanych w latach 19191920 w czasopiśmie „Przegląd Graficzny” (ibidem, s. 12).

19 Ibidem, s. 15.

20 Oprócz Gawędy w ramach tej samej serii wydane zostały jeszcze cztery inne teksty Zegadłowicza (Głośniki płonace — t. 1, Aktor Wieczny - t. 4, Nad brzegami zodiaku - t. 12 oraz Tematy rumuńskie - t. 16, a ponadto: Btękitna Godzina Artura Marii Swinarskiego (t. 3), Dziesięciolecie Książki Zegadłowicza w Poznaniu Jana Kuglina (t. 5), Ondraszkowe Ostatki Gustawa Morcinka (t. 6), Ballady Poznańskie (t. 7) i Kantyczki śnieżne (t. 17) Jana Sztaudyngera, Poranek goryczy (t. 8) oraz Kobiety i konie (t. 14) Mariana Czuchnowskiego, Błękitna defilada Michała Rusinka (t. 9), Stanisława Wysocka Stefana Papée (t. 10), Pieczęcie Marii Sewi (t. 11), Lata szkolne Jana Kasprowicza Wandy Brzeskiej (t. 13) oraz Rejs do Rygi Zbigniewa Jasińskiego (t. 15). Zob. również J. Kuglin, op. cit., s. 30-32; Biblioteka Studwudziestu, oprac. A. Jazdon, Poznań 2007. 
drukarzy, której źródła dopatrywać się można choćby w bogatej kolekcji starodruków $^{21}$, poeta śmiało dorównuje bowiem specjalistom. Za sprawą zaś pełnego lekkości i poetyckości sposobu prowadzenia wywód Zegadłowicza jest jednocześnie przystępny i atrakcyjny dla każdego. Nawiasem mówiąc, trudno tu o bardziej adekwatny tytuł, bo tekst jest $w$ istocie gawędą o pracy drukarza. O tym, jak przychodzi mu mierzyć się z codziennością pełną mało ambitnych zleceń w nadziei, że pewnego dnia trafi się materiał „najwyższego gatunku i najczystszej próby”22, który pozwoli mu pokazać pełnię jego możliwości i który już w pierwszym momencie wywoła wrażenie podobne jak u malarza:

który myśl krajobrazu pojął, uczuciem przepoił, myślą utrwalił — widzi przed sobą w okamgnieniu farby, których mu zażyć wypadnie, aby dać to co najważniejsze i najkonieczniejsze — tak i drukarzowi we wzroku wewnętrznym zjawiają się: - format - stronnica - kolumna układ - paginacja - margines - vacaty i - czcionki! — Przede wszystkiem czcionki! ${ }^{23}$

W tym miejscu można by raz jeszcze powtórzyć za poetą: „Przede wszystkiem czcionki!", gdyż z całego procesu pracy nad wydaniem książki to właśnie one przykuwają najwięcej uwagi Zegadłowicza, bo są tym, co go „najgłębiej w zakresie stronnicy drukowanej wzrusza" 24 . Przy czym opisuje je w sposób tak oddziałujący na wyobraźnię, że trudno później myśleć o nich jako nieożywionych, leżących spokojnie w kasztach. Bo według poety:

są tedy czcionki radosne i roześmiane cicho i dyskretnie, to znów gwarne i rozgłośnie, są czcionki taczające się ze śmiechu gwałtownego, są inne pokorne, uległe - inne znów dumne i pyszne, jeszcze inne smutne i zastygłe w bólu, przeraźliwe i makabryczne — ponure, martwe, zimne, opuszczone, dalekie, są groteskowe, upiorne, pajacowate — są słoneczne i północne, wiosenne i zimowe, ślepe i ostrowidzące, głuche i o wyostrzonym słuchu, niemowne i gadatliwe, cnotliwe, grzeszne, rozpustne, wyuzdane - są czcionki wszelkie! $!^{25}$

\section{I to czcionka jest:}

instrumentem głównym drukarza [...] i czcionki tej krój (z barwą zespolony), oraz forma (wykres psychiczny), które składają się na żywą istność tego tajemniczego symbolu, hieroglify mowy, myśli i uczuć - w sumie: symbolu utrwalającego przebyt ziemski ducha i jego niebiańskie tęsknoty, czy infernalne upadki ${ }^{26}$.

Bo wszak:

Pismo, dukt jego, a dziś drukarska formacja jego, ma swoją alchemję i czarodziejstwo, magję i mistykę; - dziś - może zastygłe w stereotypowości i martwocie pozornej bo chwilowej dla widzącego przemawiają olbrzymią rozpiętością przemian od bełkotu praczłowieka, poprzez

21 W kolekcji Zegadłowicza znajdowały się między innymi druki Jana Hallera, Floriana Unglera oraz Jana Januszowskiego (J. Kuglin, op. cit., s. 22).

22 E. Zegadłowicz, op. cit., s. [5].

23 Ibidem, s. [7] (we wszystkich cytatach zachowana została oryginalna pisownia oraz przyjęte przez Zegadłowicza wyróżnienia).

24 Ibidem, s. [9].

25 Ibidem, s. [9-10].

${ }^{26}$ Ibidem, s. [8-9]. 
węzły i karby, klinowe cegły, hieroglify, symbolikę tarotową, i zodjakalną — aż po szwabachę, antykwę, kursywę, elzewir, garamond, walbaum czy medjawal; — w literze każdej utajona jest, w literze i znaku pisarskim każdym, olbrzymia droga rozwoju myśli niebosiężnej człowieka, jak ból małży w perle, jak sen mroku podziemnego w złocie ${ }^{27}$.

Ale jak jednocześnie zauważa, brutalnie ściągając czytelnika na ziemię, ów magiczny charakter jest obcy czcionkom używanym przez jemu współczesnych drukarzy, którzy do swej dyspozycji mają jedynie czcionki „ułomne i niepełne”28. Te przepojone alchemią dopiero bowiem, jego zdaniem, powstaną. Jednak by tak się stało, konieczne jest przede wszystkim sprawienie, by drukarstwo, rezygnując z udogodnień technologicznych, których wówczas - w rezultacie rewolucji przemysłowej — było już sporo, uznane zostało za sztukę, a drukarze, postępując zgodnie z tą kwalifikacją, działali jak artyści.

W pewnej mierze postulat ten nie był nowy, bo po raz pierwszy wysunięto go już u schyłku XIX stulecia, w czasach narodzin nurtu „pięknej książki”" oraz ruchu Arts and Crafts ${ }^{29}$. Wtedy to William Morris, czołowy przedstawiciel nowego myślenia o sztuce, twierdził, iż „Z punktu widzenia warunków życia, produkcja maszynowa sama w sobie jest już złem"30, a podążający jego śladem Walter Crane głosił, że „właściwe korzenie i podłoże wszelkich sztuk znajdują się w rzemiośle"31, wobec czego należy dążyć do ,przemiany naszych artystów w rzemieślników, a naszych rzemieślników w artystów"32.

Koncepcja Zegadłowicza szła jednak jeszcze dalej, wykraczając poza ramy sztuki stosowanej propagowanej w kręgu Morrisa (którą — nota bene - uważał za dotąd najznamienitszą ${ }^{33}$ ). Zdaniem gorzeńskiego poety „pojęcie sztuki stosowanej w drukarstwie to rezygnacja ze znacznie dalszych i górniejszych ambicyj, których twórcze ziszczenie leży w zakresie drukarza-twórcy"34. Ale wystarczy, że:

papier, rozmiar, kolumna, czcion ka w jej biologicznym i psychologicznym doborze — stanie się dla operującego tym materiałem — tem, czem pędzle i paleta i farba dla malarza, czem instrument muzyczny dla muzyka, czem glina, kamień, marmur, bronz dla rzeźbiarza, czem cegła, zaprawa

27 Ibidem, s. [10].

28 Ibidem, s. [11].

${ }^{29} \mathrm{Na}$ temat ruchu Arts and Crafts zob. m.in. O.L. Triggs, Chapters in the History of the Arts and Crafts Movement, Chicago 1902; I. Anscombe, C. Gere, Arts \& Crafts. In Britain and America, London 1978; N. Pevsner, Od roku 1851 do Morrisa i ruchu Arts and Crafts, [w:] idem, Pionierzy współczesności. Od Williama Morrisa do Waltera Gropiusa, przeł. J. Wiercińska, Warszawa 1978, s. 31-59; G. Naylor, The Arts and Crafts Movement. A Study of Its Sources, Ideals and Influence on Design Theory, London 1980; I. Anscombe, Arts \& Crafts Style, Oxford 1991; E. Cumming, W. Kaplan, The Arts and Crafts Movement, London 1991; R.P. Blakesley, The Arts and Crafts Movement, London-New York 2009; M. Greensted, The Arts and Crafts Movement in Britain, Oxford 2010.

30 Cyt. za: N. Pevsner, Pionierzy współczesności..., s. 15.

31 Ibidem.

32 Ibidem.

33 E. Zegadłowicz, op. cit., s. [14].

34 Ibidem, s. [12]. 
murarska dla architekta, czem słowo dla poety, a dykcja i trafność przedzierżgnięcia się w obcą umysłowość i odczuwalność dla aktora - wtedy drukarz, pełen uświadomień i samowiedzy pełnym, twórczym, samoistnym będzie artystą ${ }^{35}$.

Gdy zaś to nastąpi, wówczas ,drukarz stanie się prawym, wolnym, a nie stosowanym - artystą, na równych prawach twórczych z kunsztem i majsterstwem wszelkiem"36, a tym samym dojdzie do zbratania drukarza z poetą i ,rozpocznie się epoka tej — której nie było jeszcze: sztuki książki wyzwolonej i wyzwalającej" 37 .

Jednakże kwestią dla Zegadłowicza najważniejszą była ,konieczność stworzenia własnej wizji książki polskiej”38, co, jak zauważał, „może nastąpić jedynie przez odkrywczą kampanję w zdobyciu własnej psychologicznej protogenitury czcionki, i to w typie różnorakim dającym się zastosować do różnorodności zadań drukarskich"39. Bo, jak pisał:

ani garamondy, ani elzewiry, ani walbaumy nic tu nie poradzą! — piękne to i szlachetne czcionki, lecz wyraz ich zastygły, choć czysty i spokojny — bezużyteczny prawie! Bo, aby się narodowej cechy melodja wypowiedzieć mogła - z ducha tajemnic tegoż narodu, $\mathrm{z}$ podłoża najgłębszego jego rasy wyróść musi. - I oto będzie na drodze stronicy polskiej i książki polskiej krok pierwszy i pierwszy zaczyn ${ }^{40}$.

Tym samym Zegadłowicz podjął w swym utworze temat, który w owym czasie był jednym z najczęściej poruszanych podczas dyskusji prowadzonych w kręgach osób związanych z wydawaniem książek. I choć podejmowano go już wcześniej ${ }^{41}$, to nie tak dawno odzyskana niepodległość jeszcze silniej zmotywowała do działania i przezwyciężania barier, które dotąd utrudniały, czy wręcz uniemożliwiały, stworzenie polskiego kroju pisma ${ }^{42}$. Najciekawsze, iż pierwszym typografem, który zdołał pokonać ten marazm, był zaprzyjaźniony z poetą Jan

35 Ibidem, s. [13].

36 Ibidem, s. [14].

37 Ibidem.

38 Ibidem, s. [16].

39 Ibidem.

40 Ibidem, s. [14-15].

41 Temat ten podejmowany był zresztą nieco wcześniej, bo z problemem braku polskiego kroju borykał się choćby Stanisław Wyspiański, podejmując nawet próby jego opracowania (niestety niezakończone sukcesem). Jak pisał Wincenty Trojanowski: „Wyspiański chciał nadać książce polskiej nietylko wygląd artystyczny ale pragnął, by ona mogła posią́śc charakter odrębnie-polski, wyróżniający ją od wszelkich innych europejskich, i w tym celu myślał o wynalezieniu odpowiedniego typu czcionek, przyczem wpadł na pomysł niesłychanie oryginalny i właśnie dla tego w praktyce zdaje się niewykonalny. Oto miał zebrać możliwie jak największą ilość autografów wybitnych współczesnych naszych pisarzów, artystów i uczonych i zestawienia charakteru ich pisma wyciągnąć typ ogólny, a następnie ten typ pisma przekształcić na formę liter nadających się do drukowania" (W. Trojanowski, Wyspiański. Artysta - człowiek - życie, Warszawa 1927, s. 169 - pisownia oryginalna). Zob. również: E. Skierkowska, op. cit., s. 189-192.

42 O przyczynach braku polskiego kroju pisma zob. m.in. A. Szydłowska, M. Misiak, Paneuropa, Kometa, Hel. Szkice z historii projektowania liter w Polsce, Kraków 2015, s. 27-38. 
Kuglin. To on bowiem, na użytek wydania innego tekstu swego przyjaciela Dziesięciu ballad o powsinogach beskidzkich (sierpień 1929) — zainicjował powstanie pierwszej oryginalnej polskiej czcionki, którą od nazwiska jej odlewnika nazwano antykwą Stanisława Jeżyńskiego ${ }^{43}$. I choć ów krój nie zyskał większego uznania i sam Kuglin użył go tylko trzykrotnie ${ }^{44}$, to fakt, iż się pojawił, przyczynił się do rychłego opracowania kolejnego, tym razem przyjętego powszechnie antykwy Adama Półtawskiego ${ }^{45}$.

\section{[...] nieodrębne zbratanie poety i drukarza}

O ile tekst Zegadłowiczowskiej Gawędy jest monologiem poety skierowanym do bibliofilów, a nade wszystko drukarzy, to Kuglinowe wydanie uznać można za swoistą replikę, która miast słów używa środków właściwych pracy typografa. To, czego w swej wypowiedzi domaga się poeta, w omawianym druku zyskuje materialny wymiar, a najlepszym tego dowodem jest użycie polskiej czcionki. Powstała w Rolniczej Drukarni i Księgarni Nakładowej edycja jest bowiem kolejną publikacją Kuglina, w której zastosował antykwę opracowaną przez Jeżyńskiego. Tym samym odpowiedział na najważniejszy z postulatów poety. W innych kwestiach był już jednak bardziej zachowawczy, przez co Gawęda w jego realizacji przybrała postać klasycznego druku bibliofilskiego ${ }^{46}$.

Rozmiarami niepozorna, bo licząca raptem 14 kart, Kuglinowa edycja została zatem wytłoczona na wysokiej jakości papierze ręcznie czerpanym. Druk wykonano czarną i czerwoną farbą drukarską, drugiej z nich używając do wyróżnienia tytułu (il. 1) oraz złożonego majuskułą pierwszego wiersza całego tekstu, a także znaków ornamentacyjnych służących do zaznaczenia akapitów (il. 2). Całość złożono bez wcięć akapitowych, a także znaków dzielenia, z wierszami zamykającymi poszczególne ustępy zawsze dopełnionymi do końca, co pozwoliło nadać każ-

43 Znakomity opis genezy kroju opracowanego przez Jeżyńskiego zamieścił Kuglin we wstępie do Dziesięciu ballad zatytułowanym Od typografa (E. Zegadłowicz, Dziesięć ballad o powsinogach beskidzkich, Poznań 1929, s. X-XI).

44 Oprócz Dziesięciu ballad antykwą Jeżyńskiego złożone zostały: Gawęda poety z typografem i Do Jana Kuglina w Poznaniu (Poznań 1929).

45 Warto zauważyć, iż niektórzy badacze całkowicie pomijają wkład Kuglina w rozwój polskich krojów pisma i za pierwszą oryginalną polską czcionkę uznają dopiero antykwę Półtawskiego (zob. J. Sowiński, Sztuka typograficzna..., s. 107-112).

46 O takim jej charakterze przesądziła przede wszystkim wyraźna predylekcja Kuglina do tej formy wydawniczej, decyzja, by wydać ją w ramach „Biblioteki Studwudziestu”, z założenia będącej bibliofilską, wiązała się bowiem głównie z wysokością nakładu, gdyż formuła serii nie była nazbyt sztywna i „,każdy z tomów odznaczać się miał indywidualnym opracowaniem graficznym" (E. Kuglin, op. cit., s. 30). 
dej kolumnie kształt idealnego prostokąta. W poszczególnych kolumnach (poza szpicowymi, które zamykają cały tekst) ulokowano po trzydzieści sześć wierszy, w każdym z nich mieszcząc średnio około pięćdziesięciu znaków, co czyni tekst bardzo czytelnym i mimo niezastosowania dzielenia wyrazów, a tym samym koniecznością ich „odtwarzania”, nie utrudnia jego lektury.

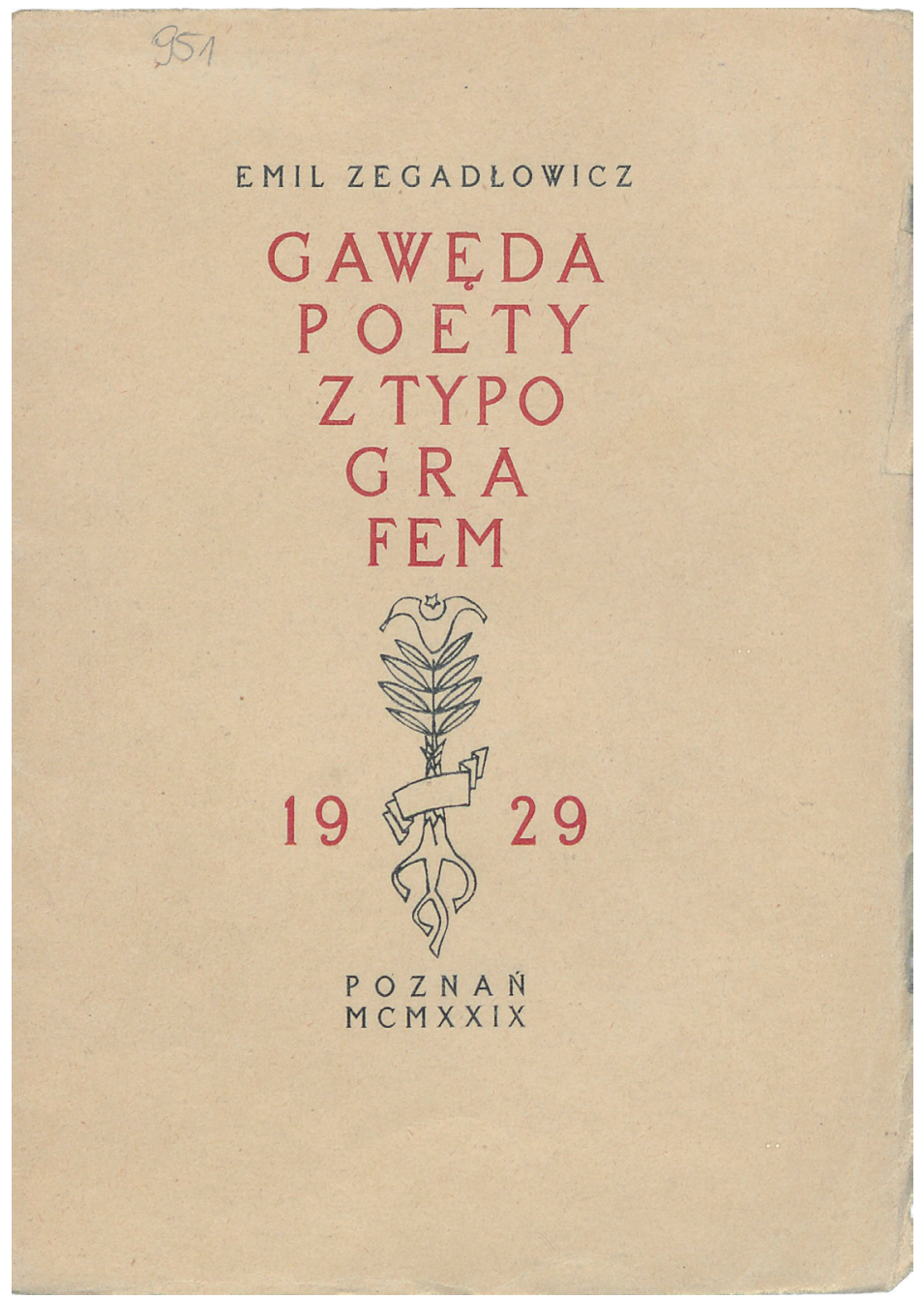

Ilustracja 1. E. Zegadłowicz, Gawęda poety z typografem, Poznań 1929 — karta tytułowa (egz. ze zbiorów Biblioteki Cyfrowej POLONA, sygn. II 864.951 A) 
NIE WIEM, CZY ROZWAZNIE I ROZTROPNIE postąpil Komitet Organizacyiny III-go Zjazdu Bt bljofilow Polskich, zebranych $z$ okazji 100-letntej rocznicy przeslawnego Ossolineum -zapraszając do referatowego dzialu - poetę! - Osobíscie $z$ nając ten genus humanum niejako $z$ autopsil, mialbym caly szereg poważnych zastrzeżeń. a przedewszystkiem to jedno, że dzis gdy szla chetna, kto wie, może najszlachetniejsza milośc do ksiąg, bibljofilstwo, staje stę $z$ dnia na dzień coraz skrupulatntejszą wiedzą, o tendencjach wy rażnie naukowych, kodyfikacyinych i statystycz nych - przekorna lotność imaginacji poetyckiej czyni w tym budującym się - nteco chińskim murze wylom, a wylomem tym wprowadza czeredę niespokojnych i niepokojących, lotnych duchów fantastycznego autoramentu. Gdy już jednak Komitet organizacyiny $w$ przynaglonej alteracji przedzjazdowej tak postapić postanowil i w naj dalej idącej tolerancji poecie glos oddać uznal za sluszne i stosowne - trzeba mi tutaj obronę tego kroku przeprowadzić o ile, o tyle mocna, a w każ dym razie wykazująca slusznosc tego pięknego, acz niebezpiecznego postanowienia. Oprzeć mi się należy sila kontrastu w stosunku do ważkich. katedralnych wywodów na niezawodzącej nigdy

Ilustracja 2. E. Zegadłowicz, Gawęda poety z typografem, Poznań 1929 — karta (egz. ze zbiorów Biblioteki Cyfrowej POLONA, sygn. II 864.951 A)

Format Gawędy to $153 \times 217 \mathrm{~mm}$. Proporcje szerokości do wysokości zbliżone są tu zatem do jednej z dwóch najpopularniejszych w średniowieczu, a także jednych z bardziej klasycznych proporcji - 3: 4 (zwanych kwartą czystą) ${ }^{47}$. Jak przystało na edycję bibliofilską, kolumna Gawędy okolona jest dużą ilością światła, a jej kształt oraz położenie na stronie ujawniają inspirowanie się tradycją drukarską. Wprawdzie rozmieszczenie to odbiega nieco od wyznaczonego przebiegiem przekątnych, ale nawiązanie do tego sposobu kompozycji jest bardzo wy-

${ }^{47}$ R. Bringhurst, Elementarz stylu w typografii, przeł. D. Dziewońska, Kraków 2007, s. 160161. 
raźne. Z klasyki rozwiązań czerpie również układ marginesów: od najszerszego u dołu stronicy, po najwęższy — wewnętrzny. „Cytatów” z dawnej typografii jest zresztą więcej. Dość przywołać umieszczony na końcu druku kolofon (il. 3) ujawniający (jak w czasach paleotypów, a sięgający swymi początkami rękopisów) wszystkie szczegóły dotyczące wydania ${ }^{48}$, czy — mający porównywalną historię, odbity na ostatniej stronie sygnet drukarski (il. 4).

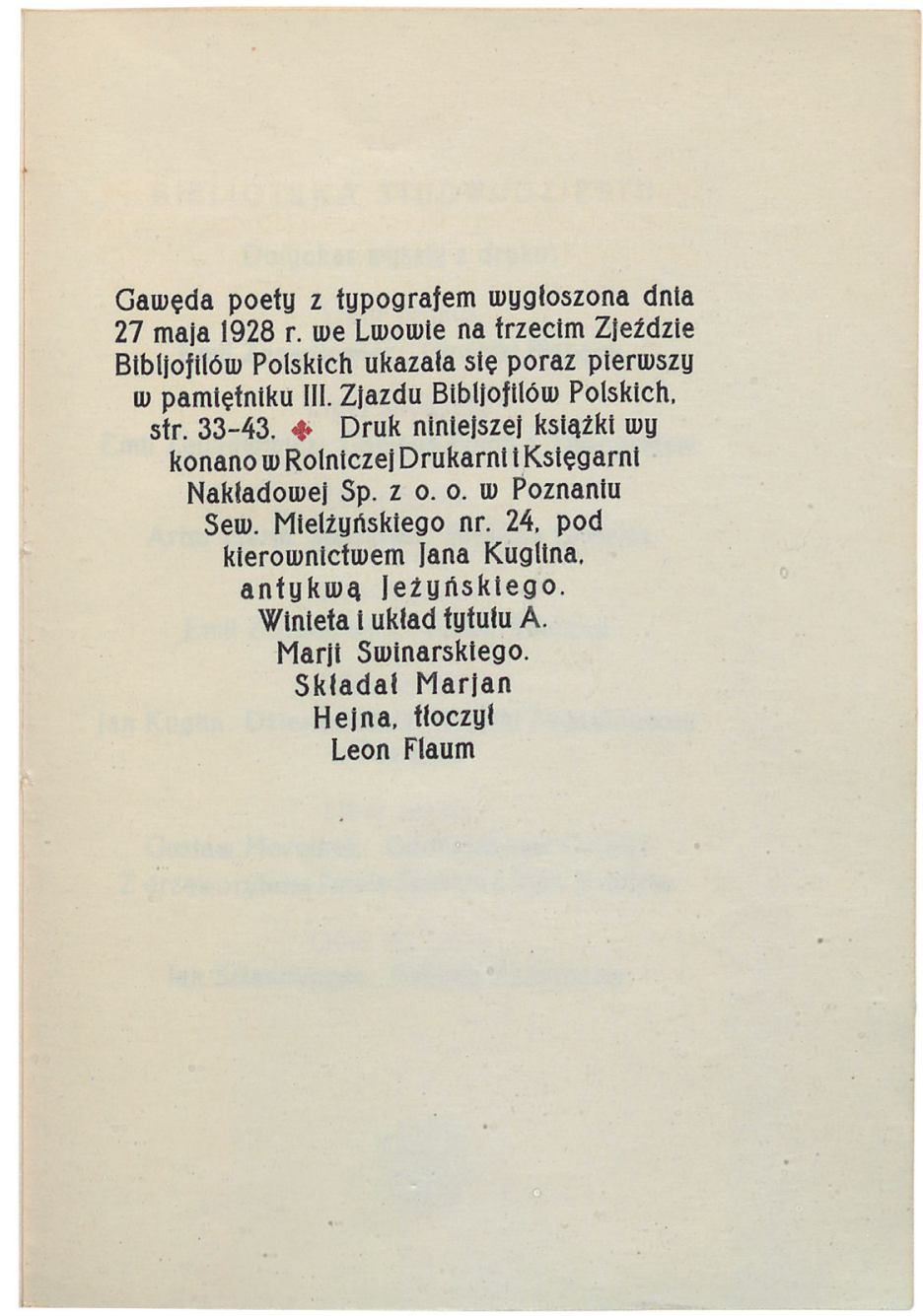

Ilustracja 3. E. Zegadłowicz, Gawęda poety z typografem, Poznań 1929 — kolofon (egz. ze zbiorów Biblioteki Cyfrowej POLONA, sygn. II 864.951 A)

48 Z kolofonu tego dowiedzieć można się między innymi, iż za winietę oraz układ tytułu Zegadłowiczowskiej Gawędy odpowiedzialny był Artur Maria Swinarski, nad składem czuwał Marian Hejna, a Leon Flaum odpowiadał za tłoczenie. 
Ilustracja 4. E. Zegadłowicz, Gawęda poety z typografem, Poznań 1929 - sygnet drukarski Jana Kuglina (egz. ze zbiorów Biblioteki Cyfrowej POLONA, sygn. II 864.951 A)

W rezultacie starań Kuglina Zegadłowiczowska Gawęda zachwyca starannością opracowania, przejawiającą się w dbałości o każdy szczegół, i jest znakomitym dowodem na to, jak piękny efekt można uzyskać, bazując jedynie na czystej formie typograficznej, czytelnej czcionce i bardzo dobrej jakości materiale. Innymi słowy - jak niewiele w istocie potrzeba, by osiągnąć doskonały rezultat, który — zważywszy na to, jak długo jeszcze później obaj twórcy z sobą współpracowali - usatysfakcjonował zarówno poetę, jak i typografa. 


\section{Bibliografia}

Anscombe I., Arts \& Crafts Style, Oxford 1991.

Anscombe I., Gere C., Arts \& Crafts. In Britain and America, London 1978.

Bąbiak G., Piękna książka na ziemiach polskich u schyłku XIX wieku, „Sztuka Edycji” 2013, nr 2, s. $19-30$.

Biblioteka Studwudziestu, oprac. A. Jazdon, Poznań 2007.

Blakesley R.P., The Arts and Crafts Movement, London-New York 2009.

Boguszewska A., ,Idea pięknej ksiązki” w dwudziestoleciu międzywojennym w Polsce, „Annales Universitatis Mariae Curie-Skłodowska Lublin Polonia" 8, 2010, s. 51-63.

Bringhurst R., Elementarz stylu w typografii, przeł. D. Dziewońska, Kraków 2007.

Christian J., A Claim to Beauty. William Morris and the Kelmscott Press, London 2013.

Cumming E., Kaplan W., The Arts and Crafts Movement, London 1991.

Dunlap R., The Road to Kelmscott. William Morris and the Book Arts before Founding of the Kelmscott Press, London 1972.

Franqueville d'Abancourt de H., Grafika książkowa Józefa Mehoffera na tle prądów współczesnych, Kraków 1929.

Greensted M., The Arts and Crafts Movement in Britain, Oxford 2010.

Kotwica A., Estetyka ksiażki a oczekiwania i potrzeby odbiorcy na przykładzie spuścizny bibliotecznej Emila Zegadłowicza, [w:] W poszukiwaniu odpowiedniej formy. Rola wydawcy, typografa, artysty i technologii w pracy nad książka, red. M. Komza przy współudziale E. Jabłońskiej-Stefanowicz i E. Repucho, Wrocław 2012, s. 321-328.

Krzak-Weiss K., Poznańskie druki bibliofilskie lat 20. minionego stulecia - coś nie tylko dla ducha, ale również dla oka, [w:] Poznań pisarek i pisarzy, red. J. Borowczyk, L. Marzec, Z. Kopeć, Poznań 2016, s. 185-199.

Kuglin J., Ze wspomnień typografa, Wrocław 1958.

Lam S., Ksiażka wytworna. Rzecz o estetyce druku, Warszawa 1922.

Lenart B., Piękna książka jako zespół całości papieru, czcionek, druku i oprawy, Poznań 1923.

Mulczyński J., Wystawy grafiki i ruch bibliofilski w Poznaniu w okresie dwudziestolecia międzywojennego, „Kronika Miasta Poznania” 1996, nr 4. Lata dwudzieste. Lata trzydzieste, s. 132-154.

Naylor G., The Arts and Crafts Movement. A Study of Its Sources, Ideals and Influence on Design Theory, London 1980.

Pamiętnik Trzeciego Zjazdu Bibljofilów Polskich we Lwowie w Zielone Świątki 26/V-29/V 1928 roku, red. K. Hartleb, Lwów 1929.

Peterson W.S., The Kelmscott Press: A History of William Morris's Typographical Adventure, Berkeley-Los Angeles 1991.

Pevsner N., Pionierzy wspótczesności. Od Williama Morrisa do Waltera Gropiusa, przeł. J. Wiercińska, Warszawa 1978.

Skierkowska E., Wyspiański - artysta książki, Wrocław 1960.

Smolik P., Zdobnictwo książki w twórczości Wyspiańskiego, Łódź 1928.

Sowiński J., Działalność edytorska towarzystw bibliofilskich w Polsce do roku 1939, „Roczniki Biblioteczne" 38, 1994, s. 155-193.

Sowiński J., Sztuka typograficzna Młodej Polski, Wrocław 1982.

Szydłowska A., Misiak M., Paneuropa, Kometa, Hel. Szkice z historii projektowania liter w Polsce, Kraków 2015.

Triggs O.L., Chapters in the History of the Arts and Crafts Movement, Chicago 1902.

Trojanowski W., Wyspiański. Artysta - człowiek - życie, Warszawa 1927.

Wiercińska J., W poszukiwaniu absolutnej harmonii, [w:] eadem, Sztuka i książka, Warszawa 1986, s. $47-75$. 
Wiercińska J., Z problematyki zdobnictwa ksiązkowego lat dziewięćdziesiatych XIX w., [w:] Sztuka około 1900. Materiały z sesji Stowarzyszenia Historyków Sztuki, Warszawa 1969, s. 223-248.

Zegadłowicz E., Dziesięć ballad o powsinogach beskidzkich, Poznań 1929.

Zegadłowicz E., Gawęda poety z typografem, Poznań 1929.

Żmuda M., Józef Mehoffer jako wspóltwórca pięknej książki polskiej (praca magisterska obroniona w 1984 roku w Instytucie Informacji Naukowej i Bibliotekoznawstwa UJ pod kierunkiem prof. dr hab. Marii Kocójowej).

\title{
How Emil Zegadłowicz discoursed about typography. Comments on the margin of the Poznan Edition of Gawęda poety z typografem of 1929
}

\begin{abstract}
Summary
The present text is based on a book by Emil Zegadłowicz published in 1929 by the poet's friend, Jan Kuglin. Gawęda poety z typografem [Discourse between a poet and a typographer] was delivered for the first time during the Third Congress of Polish Bibliophiles that took place in Lwów in 1928. Its individual fragments are a point of departure for reflections upon typography at the turn of the twentieth century, especially the beautiful book trend initiated at that time as well as the bibliophile publishing houses and editions that emerged in its wake.
\end{abstract}

KEYWORDS: Emil Zegadłowicz, Jan Kuglin, beautiful book trend, bibliophile edition, typography 